\section{ANALISIS PERMASALAHAN YANG DIHADAPI OLEH PELAKU USAHA MIKRO AGAR BERKEMBANG MENJADI USAHA KECIL (SCALLING UP) PADA UMKM DI 14 KECAMATAN DI KABUPATEN BOGOR}

\author{
Bambang Hengky Rainanto \\ Program Studi Manajemen Pemasaran, Diploma III \\ Sekolah Tinggi Ilmu Kesatuan \\ Email: hengkyrainanto@yahoo.com
}

\author{
Scalling Up, \\ UMKM, Micro \\ Bussiness, \\ Marketing
}

200

Submitted: JANUARI 2019

\section{ABSTRACT}

The existence of micro, small and medium enterprises (UMKM) has significant importance in supporting and promoting economy development in Indonesia. Other than encouraging economic growth, these UMKM have proven to reduce unemployment. UMKM contribution to gross domestic products develops from previously $57.84 \%$ to $60.34 \%$ in the last five years. The absorption of employment also rises from $96.99 \%$ to $97.22 \%$ in the same period. Of the three divisions of enterprises, micro enterprise is leading by the number followed by small and lastly medium enterprise. In terms of encouraging micro business to grow into small (scaling up), it is necessary to seek issues mostly encountered by micro business subjects. The research was administered using survey method with descriptive analysis to micro business subjects in 14 regions in Kabupaten Bogor. This is one of the efforts to clearly visualize the problems and obstacles in the development of micro business. The results found that aspects of marketing, funding, production, human resources, materials, product and production legal aspect, financial and distribution managements are among the biggest problems for the micro business in Kabupaten Bogor.

Keywords :Scalling Up, UMKM, Micro Bussiness, Marketing

\section{PENDAHULUAN}

Usaha mikro, kecil dan menengah (UMKM) memiliki peranan yang sangat vital di dalam pembangunan dan pertumbuhan ekonomi, tidak hanya di negara-negara berkembang seperti Indonesia tetapi juga di negara-negara maju. Di Indonesia peranan UMKM selain berperan dalam pertumbuhan pembangunan dan ekonomi, UMKM juga memiliki peranan yang sangat penting dalam mengatasi masalah pengangguran. Tumbuhnya usaha mikro menjadikannya sebagai sumber pertumbuhan kesempatan kerja dan pendapatan. Dengan banyak menyerap tenaga kerja berarti UMKM juga punya peran strategis dalam upaya pemerintah dalam memerangi kemiskinan dan pengangguran. Pertumbuhan Usaha Mikro, Kecil dan Menengah (UMKM) di Indonesia tidak bisa dipandang sebelah mata. Kontribusi sektor Usaha Mikro, Kecil dan Menengah (UMKM) terhadap produk domestik bruto meningkat dari 57,84\% menjadi $60,34 \%$ dalam lima tahun terakhir. Serapan tenaga kerja sektor ini juga meningkat, dari $96,99 \%$ menjadi 97,22\% pada periode waktu yang sama.

Meskipun telah terbukti bahwa UMKM mampu bertahan di saat krisis moneter, namun pertumbuhannya ternyata melambat setelah krisis moneter. Padahal saat itu diperkirakan akan lebih cepat. Seperti data yang terdapat pada Worldbank yang menunjukkan bahwa usaha kecil tumbuh lebih cepat sebelum tahun 1998 dari pada

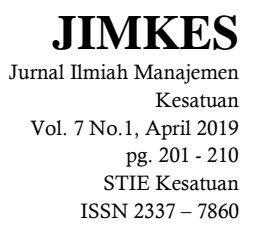


Scalling $U p$, UMKM, Micro

Bussiness, Marketing

201 sesudah tahun 1998. Meski demikian dibandingkan dengan negara tetangga lainnya, Indonesia merupakan negara yang memiliki UKM/UMKM terbesar sejak tahun 2014. Menurut data BPS 2014, jumlah UMKM di Indonesia memiliki 57,89 juta unit atau 99,99 persen dari total jumlah pelaku usaha nasional.

Berdasarkan Data Kementerian Koperasi dan UMKM, jumlah wirausahawan di Indonesia pun melonjak tajam dari 0,24 persen menjadi 1,56 persen dari jumlah penduduk. Meski begitu jumlah tersebut masih jauh dari target wirausaha Indonesia yang harusnya idealnya minimum 2 persen dari jumlah penduduk. Meski secara kuantitas jumlah wirausaha Indonesia banyak namun secara persentase jumlah tersebut kalah jauh dibandingkan dengan negara tetangga. Seperti Singapura sebesar 7\%, Malaysia 5\%, dan Thailand 4\%. Sementara negara-negara maju seperti Amerika Serikat dan Jepang bahkan memiliki jumlah pengusaha lebih dari $10 \%$ dari jumlah populasi. Meski masih minim, namun survei yang dilakukan oleh Global Entrepreneurship Monitor (GEM) pada tahun 2013, menunjukkan bahwa keinginan berwirausaha masyarakat Indonesia adalah yang kedua tertinggi di ASEAN setelah Filipina.

Di sisi yang lain, komposisi jumlah pelaku UMKM di Indonesia masih terfokus banyak di usaha Mikro yang memiliki aset maksimal Rp. 50 juta dengan omzet tahunan maksimal Rp. 300 juta. Kondisi ini perlu ditingkatkan agar terjadi proses "Naik Kelas" para pelaku usaha Mikro menjadi usaha Kecil. Berbeda dengan Usaha Mikro, Usaha Kecil memiliki aset dari Rp. 50 juta hingga Rp. 500 juta dengan omzet usaha dari nilai Rp. 300 juta hingga Rp. 2,5 Milyar.

Pada penelitian sebelumnya oleh Wang, Y (2016) menyebutkan bahwa hal yang paling menjadi penghambat perkembangan UMKM di negara-negara berkembang adalah: akses kepada keuangan, pajak, kompetisi, listrik, dan factor-faktor politik. Yang paling besar menjadi penghalang berkembangnya UMKM disebutkan bahwa akses ke keuangan dan kompetisi. Irjayanti, M \& Azis, A.M (2012), menyebutkan bahwa ada sepuluh hambatan utama yang dihadapi oleh UKM di Indonesia, yaitu: hambatan kompetisi, akses keuangan, biaya dari energi untuk produksi, teknologi, tidak efisien biaya produksi, faktor-faktor ekonomi, keterampilan manajemen, proses, pembatasan penjualan dan bahan baku.

Caldera, Desha dan Dawe (2019) berpendapat bahwa salah satu yang menentukan kesuksesan dalam pelaksanaan bisnis yang berkelanjutan untuk UKM adalah factor internal pelaku usaha itu sendiri. Terutama faktor cara berpikir dari pelaku usaha. Sahoo, S \& Yadav S (2018) menyebutkan bahwa perlunya menghadopsi Total Quality Management untuk menjalankan UKM agar berhasil. Beberapa hal yang dilakukan untuk Total Quality Management di sebuah perusahaan besar dan UKM adalah: (1) Manajemen Kualitas saat proses, (2) Pemberdayaan, (3) Pelatihan karyawan, dan (4) Memanfatkan media informasi.

Berdasarkan beberapa fenomena yang terjadi di dalam negeri dan luar negeri akan faktor-faktor yang menjadi penghalang perkembangan UMKM, melalui penelitian ini diharapkan dapat diketahui penyebab pasti yang menghambat pertumbuhan UMKM di Kabupaten Bogor.

Dari beberapa penelitian dan literasi yang ada, beberapa hal yang menjadi problematika pelaku usaha Mikro antara lain adalah masalah: Pemasaran, Permodalan, Distribusi, Perizinan dan Pengelolaan Keuangan. Di pelaksanaan klinik pendampingan awal di Kabupaten Bogor, ditemukan beberapa kendala lain yang menghambat perkembangan usaha Mikro antara lain: Ketersediaan Sumber Daya Manusia terampil, ketersediaan bahan baku yang berkualitas dan stabil, lokasi usaha yang masih bercampur dengan rumah, kebutuhan akan kemitraan dengan pemberi modal atau pelaku pasar, serta 
motivasi pelaku usaha yang masih kurang karena merupakan sumber pendapatan sampingan.

\section{TINJAUAN PUSTAKA}

Wirausaha atau wiraswasta adalah proses mengidentifikasi, mengembangkan, dan membawa visi untuk menjalankan usaha ke dalam kehidupan. Visi bias berupa ide inovatif, peluang, atau cara yang lebih baik dalam menajalankan usaha. Darmanto, Wardana \& Sulistyani (2018).

Pemberdayaan usaha mikro, kecil dan menengah (UMKM) dan Koperasi merupakan langkah yang strategis dalam meningkatkan dan memperkuat dasar kehidupan perekonomian dari sebagian terbesar rakyat Indonesia, khususnya melalui penyediaan lapangan kerja dan mengurangi kesenjangan dan tingkat kemiskinan. Dalam konteks Usaha Mikro, Kecil, dan menengah (UMKM) unit usaha secara alami akan tumbuh dari usaha yang kecil menjadi unit usaha yang besar (Bappenas, 2016).

Kewirausahaan adalah sebuah fakta bahwa peluang tidaklah hanya ditunggu secara pasif. Kewirausahaan haruslah dilakukan dengan cara mencari peluang, sehingga seorang pengusaha perlu mengembangkan diri dalam mengoptimalisasi sumber daya yang ada. Cuervo A, Ribeiro, Roig S (2007).

Tidak ada satu definisi yang sama tentang UMKM. Masing-masing negara memiliki kriteria dan definisi tersendiri akan UMKM. Secara umum, UMKM didefinisikan dari sebuah usaha yang ukurannya lebih kecil dibandingkan perusahaan besar. Ukuran tersebut salah satunya dilihat dari jumlah karyawannya. Misalnya di Uni Eropa, perusahaan UMKM adalah yang memiliki karyawan kurang dari 250 orang (OECD, 2006).

Definisi usaha mikro, kecil, dan menengah menurut undang-undang republik indonesia nomor 20 tahun 2008 tentang mikro, kecil, dan menengah pada Bab I Ketentuan Umum, Pasal 1 yaitu :

1. Usaha Mikro adalah usaha produktif milik orang perorangan dan/atau badan usaha perorangan yang memenuhi kriteria Usaha Mikro sebagaimana diatur dalam UndangUndang ini.

2. Usaha Kecil adalah usaha ekonomi produktif yang berdiri sendiri, yang dilakukan oleh orang perorangan atau badan usaha yang bukan merupakan anak perusahaan atau bukan cabang perusahaan yang dimiliki, dikuasai, atau menjadi bagian baik langsung maupun tidak langsung dari Usaha Menengah atau Usaha Besar yang memenuhi kriteria Usaha Kecil sebagaimana dimaksud dalam Undang-Undang ini.

3. Usaha Menengah adalah usaha ekonomi produktif yang berdiri sendiri, yang dilakukan oleh orang perorangan atau badan usaha yang bukan merupakan anak perusahaan atau cabang perusahaan yang dimiliki, dikuasai, atau menjadi bagian baik langsung maupun tidak langsung dengan Usaha Kecil atau Usaha Besar dengan jumlah kekayaan bersih atau hasil penjualan tahunan sebagaimana diatur dalam UndangUndang ini.

Pada Undang-Undang tersebut juga mencantumkan tentang Asas dan Tujuan dari UMKM, yang terdapat pada Pasal 2, yang berbunyi: Usaha Mikro, Kecil, dan Menengah berasaskan:
a. kekeluargaan;
b. demokrasi ekonomi;
c. kebersamaan;
d. efisiensi berkeadilan;

Scalling Up,

UMKM, Micro

Bussiness,

Marketing

202 
Scalling $U p$, UMKM, Micro

Bussiness, Marketing e. berkelanjutan;

f. berwawasan lingkungan;

g. kemandirian;

h. keseimbangan kemajuan; dan

i. kesatuan ekonomi nasional.

Kemudian, pada pasal 3 menjelaskan tentang tujuan dari Usaha Mikro, Kecil, dan Menengah adalah untuk menumbuhkan dan mengembangkan usahanya dalam rangka membangun perekonomian nasional berdasarkan demokrasi ekonomi yang berkeadilan.

Kriteria dari UMKM menurut Undang-undang yang sama terdapat di Bab IV, Pasal 6 adalah sebagai berikut:

1) Usaha Mikro memiliki kekayaan bersih paling banyak Rp50.000.000,00 (lima puluh juta rupiah) tidak termasuk tanah dan bangunan tempat usaha; atau memiliki hasil penjualan tahunan paling banyak Rp300.000.000,00 (tiga ratus juta rupiah).

2) Kriteria Usaha Kecil adalah sebagai berikut: memiliki kekayaan bersih lebih dari Rp50.000.000,00 (lima puluh juta rupiah) sampai dengan paling banyak Rp500.000.000,00 (lima ratus juta rupiah) tidak termasuk tanah dan bangunan tempat usaha; atau memiliki memiliki hasil penjualan tahunan lebih dari Rp 300.000.000,00 (tiga ratus juta rupiah) sampai dengan paling banyak Rp2.500.000.000,00 (dua milyar lima ratus juta rupiah).

3) Kriteria Usaha Menengah adalah sebagai berikut: memiliki kekayaan bersih lebih dari Rp500.000.000,00 (lima ratus juta rupiah) sampai dengan paling banyak Rp10.000.000.000,00 (sepuluh milyar rupiah) tidak termasuk tanah dan bangunan tempat usaha; atau memiliki hasil penjualan tahunan lebih dari Rp 2.500.000.000,00 (dua milyar lima ratus juta rupiah) sampai dengan paling banyak Rp50.000.000.000,00 (lima puluh milyar rupiah).

Perbedaan nilai aset dan omzet dari pelaku usaha Mikro, Kecil dan Menengah dapat dilihat pada Gambar berikut ini:

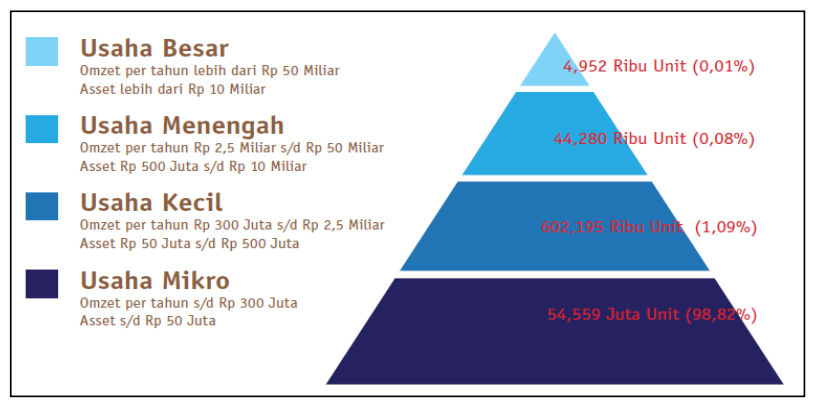

Gambar 1. Perbedaan Nilai Aset dan Omzet Usaha Mikro, Kecil, Menengah dan Besar

UMKM sebagai pembayar pajak dan pembuka lapagan pekerjaan di suatu negara tidak terlepas dari hambatan dan persoalan. Persoalan tersebut dapat menghambat UMKM untuk bisa menjalankan bisnis secara berkelanjutan. Permasalahan yang ada di UMKM diantaranya adalah: (a) Kesulitan mendapatkan karyawan yang berkualitas, (b) Kompetisi yang kurang adil, karena tidak ada control dari pemerintah, (c) Permasalahan dalam proses perijinan, (d) Kurangnya dukungan dari pemerintah, serta (e) Kesulitan keuangan (Gunerergin, M., Penbek, S., \& Zaptcioglu, D. 2012). 
Obyek dalam penelitian ini adalah 250 pelaku Usaha Mikro yang berada di 14 Kecamatan dari jumlah total 40 kecamatan yang dimiliki oleh Kabupaten Bogor. Ke-14 Kecamatan tersebut antara lain adalah:

1. Kecamatan Cibinong

2. Kecamatan Gunung Putri

3. Kecamatan Tajur Halang

4. Kecamatan Ciampea

5. Kecamatan Ciseeng

6. Kecamatan Dramaga

7. Kecamatan Ciomas

8. Kecamatan Ciawi

9. Kecamatan Caringin

10. Kecamatan Sukaraja

11. Kecamatan Bojonggede

12. Kecamatan Babakan Madang

13. Kecamatan Rancabungur

14. Kecamatan Citeurep

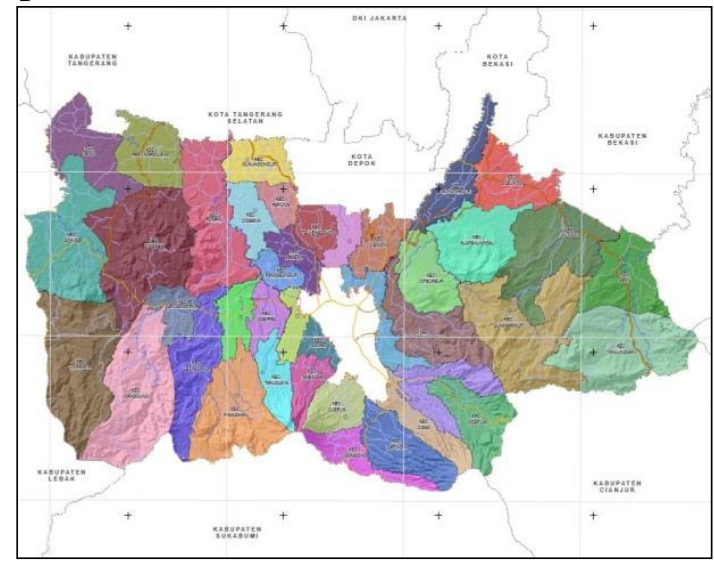

Gambar 2. Peta Kabupaten Bogor

Dipilihnya ke-14 Kecamatan tersebut sebagai Pilot Project atas keputusan dari Kantor Dinas koperasi dan Usaha Mikro, Kecil dan Menengah (UMKM). Pertimbangan pemilihan ke-14 kecamatan tersebut salah satunya alasan karena secara letaknya dekat dengan ibukota Kabupaten Cibinong dan Kota Bogor. Pemilihan lokasi ini juga mempertimbangkan kemudahan akses pelaku Usaha Mikro ke Ibukota Kabupaten Bogor yaitu Cibinong dan Kota Bogor sebagai tujuan dari pemasaran produk-produk yang dibuat.

Penelitian ini merupakan penelitian dekriptif, data yang digunakan adalah data kuantitatif dan kualitatif, yang berupa data primer dan data sekunder. Proses pengumpulan data primer dilakukan pada bulan Juli 2018 hingga November tahun 2018.

Populasi pada penelitian ini berdasarkan pada database yang dimiliki oleh dirilis dari Bappeda Litbang Kabupaten Bogor hingga tahun 2016 berjumlah 734.310 usaha.

Metode analisis yang digunakan adalah :

a. Tabulasi Data

b. Reduksi Data

c. Analisis Deskriptif 
Scalling $U p, \quad$ Kerangka Pemikiran

UMKM, Micro

Bussiness,

Marketing

205

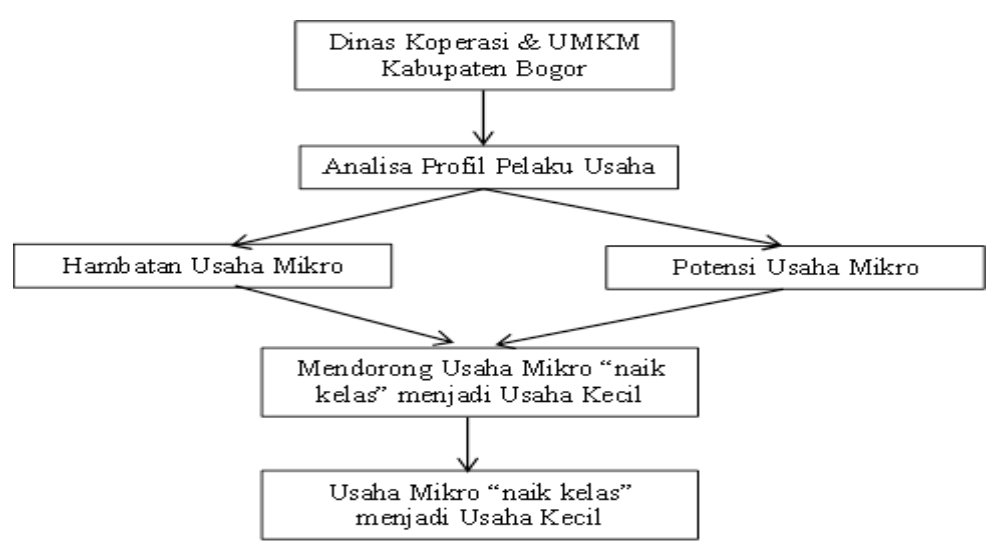

\section{HASIL DAN PEMBAHASAN}

\section{Profil Responden}

a. Karaterisik Responden Berdasarkan Jenis Kelamin dan Profil Responden

Responden sebagai obyek penelitian ini sebagian besar berjenis kelamin Perempuan $(71,50 \%)$. Mereka adalah para ibu rumah tangga yang mengisi waktunya dengan memanfaatkan fasilitas yang ada di rumahnya, tentunya ditambah peralatan dan bahan lain bilsa dibutuhkan. Motifasi para ibu rumah tangga tersebut adalah untuk mencari tambahan penghasilan selain mengisi waktu luang.

b. Karakteristik Responden Berdasarkan Jenis Usaha

Sebagian besar responden pelaku usaha mikro yang ada di Kabupaten Bogor dan menjadi obyek penelitian bergerak bi bidang makanan \& minuman $(65,1 \%)$. Mereka para ibu-ibu yang memiliki keterampilan dalam membuat berbagai macam penganan. Sebagian besar dari mereka menjadikan usaha mikro tersebut sebagai pengisi di waktu luang (sambilan), sehingga tujuan pengelolaan usaha mikro tersebut bukan menjadi pendapatan utama keluarga. Jenis usaha usaha mikro yang lain setelah usaha makanan dan minuman adalah Fashion $(18,23 \%)$, Kerajinan Tangan $(5,21 \%)$, Logam $(2,08 \%)$, Peternakan $(1,04 \%)$ dan beragam $(8,33 \%)$.

Dari aspek manajemen keuangan, sebagian besar mereka mencampurkan antara uang usaha mikro dengan uang kebutuhan rumah tangga. Hal ini yang menjadi kesulitan untuk pengembangan, terutama bila usaha tersebut akan dikembangkan dan membutuhkan dana dari pihak lain (bank). Salah satu persyaratan yang diminta oleh pihak pemberi pinjaman adalah laporan keuangan.

c. Karakteristik Responden Berdasarkan Jenis Pendapatan

Karena merupakan pendapatan sampingan, maka motivasi yang dimiliki oleh pelaku usaha mikro tidaklah sebesar bila menjadi pendapatan utama.

Terdapat hubungan antara jenis kelamin dengan jenis pendapatan. Sebagian besar pelaku usaha mikro berjenis kelamin perempuan menjadikan usahanya sebagai pendapatan sampingan, namun bagi pelaku usaha berjenis kelamin laki-laki menjadikan usahanya sebagai pendapatan utama.

Permasalahan yang terjadi dalam rangka Naik Kelas dari Usaha Mikro menjadi Usaha Kecil

a. Aspek Pemasaran, Desain dan Pengepakan 
Aspek pemasaran merupakan yang paling banyak dikeluhkan oleh para pelaku usaha mikro. Sebagian mereka energinya sudah banyak terkuras untuk memproduksi produk usahanya, sehingga tinggal tersisa sedikit untuk upaya pemasaran. Sebanyak $62,89 \%$ pelaku usaha mikro yang disurvey mengeluhkan permasalahan di bidang pemasaran, desain dan pengepakan.

Selain itu, permasalahan pemasaran yang sering diutarakan oleh para pelaku usaha Mikro adalah Pemasaran Digital. Digital marketing merupakan cara-cara pemasaran yang lebih maju dengan memanfaatkan ilmu pengetahuan dan teknologi. Digital marketing di era kini menggunakan data-data yang diolah dengan program tertentu dan mudah disebarluaskan menggunakan alat komunikasi mobile (HP, Laptop, Tablet, dll) (Ryan, 2017).

Permasalahan terkait dengan pemasaran digital yang dialami oleh para pelaku usaha mikro tersebut dapat dipahami karena sebagian besar mereka merupakan generasi yang saat ini berusia 40 tahunan, bahkan ada beberapa yang sudah berusaia 50 tahunan. Di generasi tersebut, tidak banyak yang memahami bagaimana cara melakukan upaya pemasaran dengan memanfaatkan alat komunikasi mobile. Berbeda halnya dengan generasi milenial yang ada di bawahnya. Sebagian dari pelaku usaha masih menggunakan cara-cara pemasaran yang konvensional.

Penggunaan alat komunikasi mobile hanya terbatas untuk pertemanan. Seandainya sebagian mereka sudah memiliki akun khusus untuk pemasaran, namun sering kali ditemui adanya stagnasi informasi dan upaya pemasaran di akun tersebut. Akibat dari hal ini adalah iklan produk menjadi kurang menarik bagi konsumen.

b. Aspek Permodalan dan Kerjasama

Terdapat $42,78 \%$ pelaku usaha mikro di ke-14 kecamatan yang mengeluhkan segi permodalan dan kerjasama sebagai hambatan mereka untuk maju menjadi usaha kecil.

Khusus untuk aspek permodalan, beberapa pelaku usaha mikro membutuhkan modal dalam jumlah yang cukup besar pada waktu-waktu tertentu, misalnya saat bulan puasa ramadhan, menjelang lebaran dan liburan panjang. Mereka membutuhkan saat itu karena permintaan dari konsumen melonjak. Sedangkan di waktu-waktu yang lain cenderung stabil atau bahkan rendah.

Kebutuhan modal dengan karakteristik musiman tersebut memang agak menyulitkan bagi pelaku usaha. Di sisi yang lain, pemberi pinjaman seperti bank juga tidak terlalu tertarik untuk memberikan pinjaman dengan sistem bisnis musiman. Bank pastinya akan memilih usaha-usaha yang perputaran uangnya cenderung stabil dan memiliki prospek jangka panjang.

Permasalahan permodalan yang menjadi keluhan adalah keinginan bagi sebagian pelaku UMKM berharap pinjaman tanpa Riba. Mereka berharap model pemberian modal menggunakan prinsip syariah dengan konsep bagi hasil. Dalam hal ini, tidak mudah mencari pihak ketiga yang mau menjadi investor UMKM dengan sistem ini. Seandainya adapun, mereka juga pasti akan memilih UMKM apa saja yang akan didanai.

c. Aspek Produksi

Permasalahan yang banyak ditemukan di aspek produksi adalah terdiri dari sarana produksi, tempat produksi dan proses produksi. Terdapat $30,41 \%$ pelaku usaha mikro yang mengeluhkan tentang Sarana Produksi, Tempat Produksi dan Proses Produksi dalam mengembangkan usahanya.

Masih menjadi satunya ruang produksi untuk usaha Mikro dengan dapur untuk rumah tangga para pelaku usaha membuat proses produksi kurang optimal. Beberapa hal yang bisa berdampak negatif dari satunya dapur sebagai lokasi produksi antara lain adalah:

(1) Standar kualitas (rasa dan ukuran), 
Scalling Up,

UMKM, Micro

Bussiness,

Marketing

207
(2) Alat produksi, seperti kompor, tabung gas, panci, kulkas, penggorengan, dll

(3) Bahan produksi

(4) Pendukung produksi, seperti kendaraan, rumah merangkap kantor atau toko, dll.

\section{d. Aspek SDM}

Keterampilan untuk memproduksi yang dimiliki oleh sumber daya yang ada di usaha mikro menjadi kendala karena sebagian pelaku usaha atau karyawan didapatkan dari orang yang ada di sekitar dan tidak memiliki latar belakang keterampilan tersebut. Pelaku usaha yang mempekerjakan orang biasanya dengan latar belakang pendidikan yang rendah. Mereka akan mengajarkan bagaimana memproduksi.

Terdapat 23,71\% pelaku usaha mikro yang berpendapat bahwa SDM merupakan hal yang menjadi kendala mereka dalam mengembangkan usahanya. Kendala lain di aspek SDM adalah cepatnya keluar-masuk (turn over) karyawan. Hal ini disebabkan oleh banyak faktor seperti: gaji, ijin dari pasangan, kondisi rumah tangga dan anak-anak, dan alasan lainnya.

e. Aspek Bahan Baku

Ketersediaan bahan baku dengan kualitas yang stabil dan jumlah yang cukup merupakan salah satu kendala yang cukup sering dialami oleh responden. Karena sebagian besar pelaku usaha adalah usaha mikro yang memproduksi makanan, mereka sangat terpengaruh bila ketersediaan bahan baku yang tidak stabil, bail kuantitas maupun kualitas. Terdapat $19,7 \%$ pelaku usaha mikro yang mengeluhkan bahwa bahan baku merupakan kendala mereka dalam mengembangkan usahanya.

Salah satu kendala lain yang dialami sehubungan dengan aspek bahan baku adalah ketidak-stabilan harga dari bahan baku tersebut di pasaran. Harga yang berubah-ubah tersebut cukup menganggu pelaku usaha Mikro dalam menetapkan harga jual. Apabila harga jual kepada onsumen akhir nanti juga berubah-ubah berakibat dari turunnya loyalitas konsumen dalam membeli produk dari usaha Mikro.

f. Aspek Legalitas Usaha dan Produk

Kelengkapan dokumen dalam menjalankan usaha merupakan salah satu yang menghambat Usaha Mikro. Dokumen seperti SIUP, PIRT, Akte Pendirian, Serifikat Halal MUI, Ijin edar, BPOM dan berbagai jenis dokumen legal lainnya seringkali menjadi penghambat usah mikro untuk memanjukan usahanya. Terdapat 9,79\% pelaku usaha mikro yang menilai bahwa perijinan merupakan hambatan mereka dalam mengembangkan usahanya.

Kelengkapan dokumen legal akan menentukan skala usaha karena menentukan skala pemasarannya. Bila ijinnya hanya terbatas, tidak menutup kemungkinan peredaran produknya juga hanya disekitar Bogor dan tidak diperbolehkan dijual dengan area distribusi luas.

Salah satu alasan usaha Mikro tidak mudah mendapatkan dokumen legal karena beberapa dokuemn tersebut harus dengan persyaratan yang sangat ketat seperti mengurus usaha besar. Biaya yang cukup besar dan waktu yang lama juga menjadi salah satu alasan mereka tidak mengurus perijinan untuk usaha dan produknya.

g. Aspek Manajemen Keuangan

Hambatan manajemen keuangan yang banyak dialami oleh para pelaku usaha adalah jadi satunya keuangan untuk usaha mikro dengan keuangan rumah tangga. Kondisi tersebut menyulitkan para pelaku usaha mikro untuk mengetahui apakah usahanya untung atau rugi. Terdapa 3,09\% pelaku usaha mikro yang mengalami kendala manajemen keuangan untuk mengembangkan usahnya.

Selain itu karena keterbatasan ilmu manajemen keuangan yang dimiliki oleh para pelaku usaha Mikro. Aspek manajemen keuangan juga menjadi salah satu prasyarat untuk 
mengetahui berapakah omzet dan aset usaha. Pada perkembangan berikutnya, laporan keuangan akan dibutuhkan pada saat pengajuan pinjaman atau pengajuan kerjasama usaha dengan pihak lain.

h. Aspek Distribusi

Distribusi menjadi salah satu hambatan para pelaku usaha mikro dalam mengembangkan usahanya. Terdapat $2,06 \%$ pelaku usaha mikro yang menilai bahwa distribusi merupakan kendala yang mereka hadapi dalam mengembangkan usahanya.

Sebagian besar pelaku usaha mikro menjalankan rantai distribusi yang sangat sederhana karena mereka sendiri yang melakukan pengantaran kepada pihak konsumen. Seandainya menggunakan pihak lainpun, proses ditribusi masih terbatas pada area yang terbatas di sekitar lokasi produksi dan Bogor secara umum. Belum ada pelaku usaha mikro yang secara mandiri memiliki rantai distribusi dengan area jangkauan yang luas hingga skala provinsi maupun nasional.

Tabel 1. Hasil Analisa

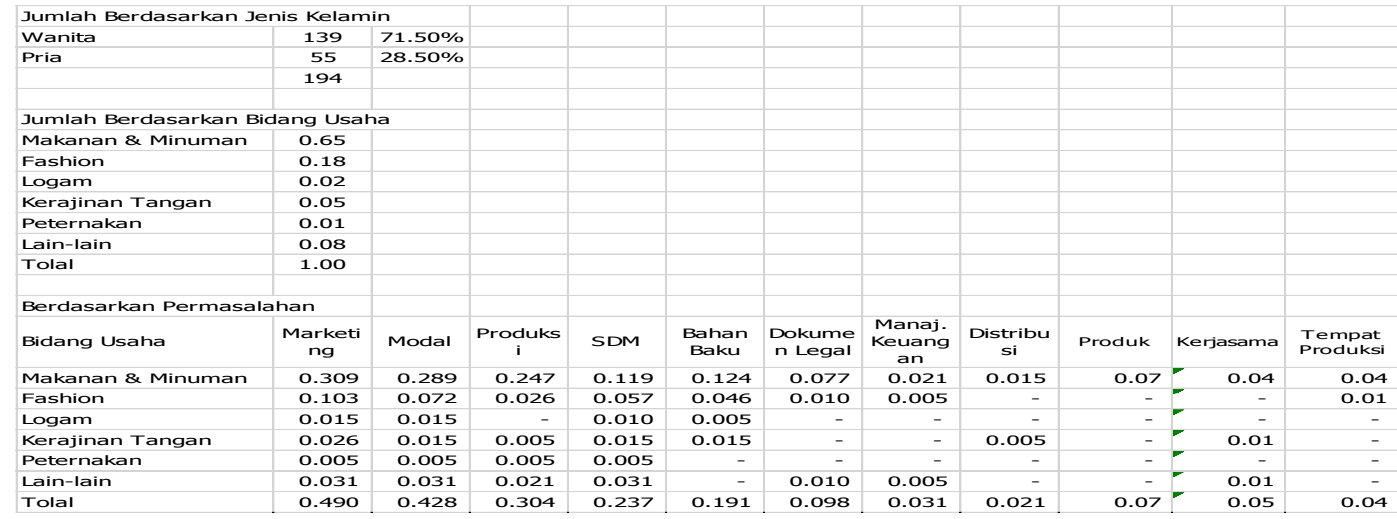

\section{Potensi Naik Kelas dari Usaha Mikro menjadi Usaha Kecil}

\section{a. Aspek Pemasaran}

Potensi pertumbuhan usaha mikro di Kabupaten Bogor sebenarnya sangat bagus. Lokasi Kabupaten Bogor yang dekat dengan ibukota negara Jakarta menjadi salah satu potensi utama. Selain itu, Kabupaten Bogor dan Kota Bogor merupakan tujuan wisata dari pelancong dari Jabodetabek, nasional maupun internasional.

Pemasaran secara on-line dengan menggunakan pemasaran digital bisa dikembangkan oleh masing-masing pelaku usaha mikro. Selain itu, perlu juga melakukan kerjasama untuk pemasaran on-line dengan akun-akun pemasaran yang sudah terkenal dan terpercaya. Harapan dari pemasaran digital untuk produk usaha mikro ini adalah terjadinya peningkatan penjualan serta penyebarluasan penjualan produk, bukan hanya konsumen di Bogor, namun bisa ke seluruh nusantara atau bahkan ke luar negeri.

b. Aspek Produksi

Yang menjadi kendala dari aspek produksi adalah menjadi satunya tempat produksi dan peralatan produksi, hal itu juga menjadi aspek yang menguntungkan bagi pelaku usaha mikro. Usaha mikro dengan dana yang terbatas bisa mengoptimalkan apa yang mereka miliki di rumah. Apabila usaha mikro tersebut meningkat dan menjadi maju, mereka bisa meningkatkan aspek-aspek produksi menjadi lebih teratur dan profesional.

c. Aspek Manajemen Keuangan

Aspek manajemen keuangan juga mempunyai potensi yang bagus bila dilakukan pelatihan tentang bagaimana cara mengelola keuangan dengan baik. Pelatihan tentang 
Scalling Up, UMKM, Micro

Bussiness, Marketing

209 pemisahan keuangan antara uang untuk rumah tangga dengan uang untuk usaha mikro menjadi kebutuhan bagi setiap pelaku usaha mikro.

Manajemen keuangan juga nantinya akan membantu para pelaku usaha dalam memahami kondisi usaha yang dijalankan. Pemahaman tentang kondisi usaha yang dijalankan akan memudahkan pelaku usaha dalam menentukan alternatif dan strategi ke depannya.

d. Aspek SDM

Ketersediaan SDM yang memiliki keterampilan yang sesuai dengan kebutuhan usaha mikro memang menjadi salah satu hambatan. Namun, di balik itu juga memiliki potensi yang baik di masa mendatang. Pengangkatan tenaga kerja biasanya dilakukan bila usaha mikro sudah mulai maju.

Pelaku usaha mikro biasanya lebih nyaman bila mengangkat tenaga kerja yang berada di sekitar tempat tinggalnya. Kondisi ini secara umum berarti mengurangi pengangguran serta meningkatkan taraf hidup masyarakat di sekitar usaha Mikro tersebut berada.

e. Aspek Permodalan

Modal yang di salah satu sisi merupakan penghambat majunya Usaha Mikro, di sisi yang lain kebutuhan modal untuk usaha mikro ini tidaklah sebanyak usaha kecil, menengah, sedang atau bahkan besar. Dengan modal yang kecil, seseorang sudah bisa memulai usaha mikronya. Berbeda dengan usaha besar yang membutuhkan dukungan dana dalam jumlah yang besar pula.

\section{SIMPULAN DAN SARAN}

\section{Simpulan}

Hasil analisa terhadap usaha Mikro di Kabupaten Bogor diketahui bahwa terdapat beberapa hambatan, yaitu: Pemasaran, terutama keterbatasan pelaku usaha mikro dalam menjalankan pemasaran digital; (2) Permodalan, pada waktu-waktu tertentu pelaku usaha mikro membutuhkan dana dalam jumlah yang cukup besar bagi mereka. Hal ini karena sebagian mereka menjalankan usaha yang sifatnya musiman. (3) Produksi, yaitu masih terbatasnya tempat produksi. Sebagian besar masih bercampur antara tempat produksi dan rumah tempat tinggal; (4) SDM, ketersediaan pegawai dengan keterampilan yang sesuai dengan bidang usaha masih terbatas. Pelaku usaha sebagian besar turun tangan untuk memproduksi, sedangkan karyawan sifatnya hanya membantu pemilik usaha; (5) Bahan Baku, Ketersediaan bahan baku yang mencakup kualitas dan kuantitasnya; (6) Legalitas dokumen, perijinan produk dan produksi; (7) Manajemen Keuangan, sepertihalnya produksi, seringkali keuangan usaha mikro masih jadi satu dengan keuangan rumah tangga; (8) Distribusi, masih terbatasnya area produksi dan rantai distribusi produk-produk usaha mikro.

\section{Saran}

Berdasarkan hasil penelitian ini beberapa sara yang dapat diberikan bagi para pelaku UMKM adalah mengikuti perkembangan terkini tentang strategi pemasaran, mengikuti pelatihan untuk memperbaiki kualitas produksi dan distribusi, serta memperbaiki manajemen keuangan. Sedangkan saran bagi penyelenggara pemerintah daerah adalah perlunya dilakukan training untuk para pelaku UMKM tentang pemasaran, produksi dan distribusi serta menajemen keuangan. Selain itu perlu dilakukan bantuan agar ketersediaan bahan baku tetap ada, dan kemudahan dalam pengurusan perijinan. 


\section{DAFTAR PUSTAKA}

Scalling Up,

Bappenas. 2016. Warta KUMKM, Direktorat Pengembangan UKM dan Koperasi Kementerian PPN/Bappenas. Volume 5-No.1-2016.

Caldera, HTS, Desha C, Dawes L. 2019. Evaluating the enablers and barriers for successful implementation of sustainable business practice in "lean" SMEs. Journal of Cleaner Production.

Cuervo A, Ribeiro D and Roig S. 2007. Entrepreneurship, Concepts, Theory and Perpective. Springer - Bancaja. New York

Darmanto, Wardaya \& Sulistyani. 2018. Kiat Percepatan Kinerja UMKM dengan model UMKM, Micro

Bussiness,

Marketing Strategi Orientasi Berbasis Lingkungan. Penerbit Deepublish (Grup Penerbitan CV Budi Utama). Yogjakarta

Firdausy, Carunia Mulya. 2017. Strategi Pengembangan Ekonomi Kreatif di Indonesia. Yayasan Pustaka Obor Indonesia.

Gunerergin, M., Penbek S, Zaptcioglu. 2012. Exploring the Problems and Advantage of Turkish SMEs for Sustainability. SciVerse ScienceDirect. Procedia - Social and Behavioral Sciences 58 (2012) 244-251.

Herawati, Tuty dan Etty K. 2016. Peluang dan Tantangan Usaha Mikro Kecil dan Menengah (UMKM) Bidang Fashin Kota Bandung dalam Menghadapi Masyarakat Ekonomi Asean. Politeknik Negeri Jakarta.

Irjayanti, M., \& Azis, A.M. 2012. Barrier Factors and Potential Solutions for Indonesia SMEs. Procedia Economics and Finance, 4,3-12.

J. Ernesto Amoros dan N. Bosma. 2013. Global Enterpreneurship Monitor, Global Report, Fifteen Years of Assessing Entrepreneurship Across The Globe. Babson, Universidad del Desarrollo, Universiti Tun Anbul Razak.

Organisation for Economic Co-Operation and Development (OECD). 2006. The SME Financing Gap, Theory and Evidence. OECD Publishing. Dancers. USA

Ryan, Damian. 2017. Understanding Digital Marketing, Marketing trategies for engaging the digital generation. Kogan Page. London. United Kingdom

Trenggana, Hendry M, Masodah dan Edi M.P. 2016. Analisis Potensi dan Hambatan yang dihadapi UMKM dalam Mengembangkan Usaha dengan menggunakan alat bantu Sistem Informasi Geografis (GIS): Studi Kasus Kecamatan Pancoran Mas, Kota Depok. Fakultas Ekonomi, Jurusan Manajemen. Universitas Gunadarma.

Undang-undang Republik Indonesia Nomor 20 Tahun 2008 tentang Usaha Mikro, Kecil, dan Menengah. Bab I, Bab II, Bab III dan Bab IV

W. Mertens, A. Pugliese and J. Recker. 2017. Quantitative Data Analysis: A Companion for Accounting and Information Research. Spinger International Publishing. Switzerland.

Wang, Yao. 2016. What are the biggest obstacles to growth of SMEs in developing countries? - An empirical evidence from an enterprise survey. Borsa Istambul Review 16-3, 167-176. 